\title{
FEDERAL TORTS CLAIMS ACT: SUPREME COURT ADOPTS STATE'S CHOICE-OF-LAW RULES
}

$T_{\text {he Federal Torts Claims Act }}{ }^{1}$ provides that the United States is liable in tort as would be a private individual "in accordance with the law of the place where the act or omission occurred."2 This language permits various interpretations concerning which law is applicable where negligence in one jurisdiction leads to injury in another. The Supreme Court resolved this problem of interpretation in the recent case of Richards v. United States. ${ }^{3}$

Suit was brought in Oklahoma alleging that negligence on the part of the United States in Oklahoma had led to the death of plaintiff's husband in an airplane crash in Missouri. ${ }^{4}$ The district court dismissed the action for failure to state a claim ${ }^{5}$ because the Oklahoma conflictof-laws rule required application of Missouri Law under which maximum recovery had already been received. ${ }^{8}$ A divided Court of Appeals affirmed, the dissent contending that only the "internal" law of Oklahoma, permitting unlimited recovery, should apply. The Supreme

\footnotetext{
${ }^{2} 60$ Stat. 842 (1946), codified in scattered sections of title 28 of the United States Code.

328 U.S.C. 1346 (b) (1959).

369 U.S. I (1962).

- The allegation was that the United States, acting through the Civil Aeronautics Administration, had negligently failed to prohibit certain repair practices in an Oklahoma airline overhaul depot. Record, p. 4 .

Although the question was not reached in this litigation, in another proceeding arising out of the same crash it was found that actionable negligence on the part of the United States was not shown. Lee v. United States, Civ. No. $335^{8}$ (N.D. Tex. 1957), cited in Brief for Appellee pp. 3-4 note 6, Richards v. United States, 285 F.2d 521 ( Ioth Cir. 1960).

- The district court decision is unreported. After a pre-trial hearing, a two-part conclusion of law was made by the court. First, it was held that the Oklahoma Wrongful Death Act, OKLA. STAT. tit. I2 $\$ \S 1053$, 1054 (195I), was inapplicable because it had no extra-territorial effect. See, e.g., Gochenour v. St. Louis San Francisco Ry., 205 Okla. 594, 239 P.2d 769 (1952). Thus, the only basis for suit was under Oklahoma's general law, applying its conflict-of-laws rules. Second, applying those rules, the suit was determined by reference to the Missouri Wrongful Death Statute, Mo. REv. STAT. $\$ \S 537.070 .100$ (1959).

- Mo. Rev. STat. \& 537.090 (1949). This amounted to $\$ 15,000$ which had been paid to some of the plaintiffs and tendered to the rest by payment into the court's regis try. These payments were made by American Airlines, a third party defendant here. The Missouri statutes were subsequently amended to allow maximum recovery of \$25,000. MO. REV. STAT. \& 537.090 (1959).

${ }^{7}$ Richards v. United States, 285 F.2d 521 (10th Cir. 1960).
} 
Court unanimously affirmed, holding that the "law" of the place of the act or omission referred to the "whole" law, including choice-of-law rules, of the place where the "acts of negligence took place."

Prior to the Richards decision, the lower federal courts had formulated three approaches in determining the law applicable in Torts Claims Act cases involving more than one jurisdiction. The Ninth Circuit had applied the law of the place where the negligence produced injury. This construction could be based upon the theory that the act was meant to embody the traditional choice-of-law rule looking directly to the place of the injury, ${ }^{10}$ or upon the conceptualistic difficulty of separating the negligent act or omission from the resultant injury. ${ }^{11}$ The District of Columbia Circuit had decided that the language of the act required application of the internal law of the place where the negligent act or omission occurred. ${ }^{12}$ The Tenth Circuit holding in the instant case, presenting the third alternative, applied the "whole" law of the place of the act or omission, including its conflict-of-laws rules. ${ }^{13}$

The Supreme Court summarily rejected application of the law of the place where the negligence produced injury as not comporting with the ordinary meaning of the statutory language. In considering the other two possibilities, both of which apparently come within the purview of the statutory phrase "law of the place," the Court recognized that congressional intent was non-existent concerning choice of law where the negligent act or omission occurred in one state and the injury in

\footnotetext{
${ }_{369}$ U.S. at Io.

- Hess v. United States, 259 F.2d 285 (9th Cir. 1958), vacated on other grounds, 361 U.S. 314 (1960); United States v. Marshall, 230 F.2d 183 (9th Cir. 1956) ; Air Transport Associates v. United States, 221 F.2d 467 (9th Cir. 1955). This approach was also taken by the unusual dissenting opinion in Eastern Air Lines v. Union Trust Co., 221 F.2d 62 (D.C. Cir. 1955).

The Hess case suggests a fourth possible alternative to the three approaches examined in the text, that the "whole law," including choice-of-laws rules, of the place of the injury be applied.

${ }^{10}$ Restatement, Conflicts of Law $\S 377$ (1934).

11 This result seems inherent in the use of such language as: "the negligence existed but was then inoperative." United States v. Marshall, 230 F.2d 183 at 187 (9th Cir. 1956).

Compare Lacey v. L.W. Wiggins Airways, Inc., 95 F. Supp. 916 (D. Mass. 1951) where similar language in the Death on the High Seas Act was construed in this aame manner.

12 Eastern Air Lines v. Union Trust Co., 221 F.2d 62 (D.C. Cir. 1955). This approach was also followed by the dissenting judge in the Tenth Circuit opinion in the instant case. See also Cook v. United States, 274 F.2d 689 (2d Cir. 1960).

${ }^{18}$ Richards v. United States, 285 F.2d 521, 524 (10th Cir. 1960). This same approach seems indicated in Landon v. United States, 197 F.2d 128 (2d Cir. 1952).
} 
another. ${ }^{14}$ However, in determining the scope of the language, the Court held that application of the "whole" law of the place of the act or omission would better effectuate the congressional policy of equating the liability of the United States with that of a "private person under like circumstances."15 That application of only the internal law is inadequate to meet this policy becomes apparent by noting that had the tort-feasor been a private individual, traditional conflict-of-laws rules would dictate a different result by applying the law of the place of injury. ${ }^{16}$

The Court also pointed out that the use of the "whole" law would provide a degree of flexibility in the area. Traditionally, choice of law in cases involving negligent conduct in one state leading to injury in another has been governed by a rigid rule requiring application of the law or the place of the injury. ${ }^{17}$ Despite constitutional overtones, ${ }^{18}$ dissatisfaction with inequities resulting from the rule's mechanical application have led to a call for a more discriminating analysis of the policies and interest of the states involved. ${ }^{19}$ Consequently, a relaxation of the

\footnotetext{
${ }^{24}$ See Goodrich, Yielding Place to New: Rest Versus Motion in the Conflict of Laws, 50 CoLUM. L. REv. 88I, 894-95 (1950). See generally 45 IOWA L. REv. 125 at 126 (1959).

${ }^{15}$ The quoted language comes from the Senate hearings on the act. S. Rep. No. 1400, 79th Cong., 2d Sess. 32 (1946).

${ }^{20}$ The dissenting opinion of Judge Magruder in Cook v. United States, 274 F.2d 689,692 (2d Cir. 1960), strikingly illustrates this aspect of the problem. It should be noted, however, that the liability of the United States and an individual tort-feasor are not congruent, even under the statute. See 68 HARv. L. REv. 1455, 1456 (1955).

The Court in the Richards case points out a similar problem arising because of the two possible venues under the statute. 369 U.S. at 12 n.25. If suit were brought at plaintiff's residence, to determine the liability of an individual the court would look directly to the law of the place of injury, assuming use of classical choice-of-law rules, but under this decision the liability of the United States is determined by reference to the law of what may possibly be a different state, i.e. that of the place of negligence, which may or may not also look to the law of the place of injury.

${ }^{27}$ An extensive analysis and listing of cases following this rule is found in Annot., 77 A.L.R.2d 1266, 1273-86 (1961).

${ }_{28}$ "[I]t is established as the law of this court that when a person recovers in one jurisdiction for a tort committed in another he does so on the ground of an obligation incurred at the place of the tort ... and that is not only the ground but the measure of the maximum recovery." Western Union Tel. Co. v. Brown, 234 U.S. 542, 547 (1914) (Holmes, J.). It should be noted, however, that both the negligent act or omission and the injury in that case occurred in the same jurisdiction.

${ }^{10}$ See, e.g., CoOK, The Logical and Legal Bases of the Conflict of LaWs: ch. I (1942); Cavers, The Two "Local Law" Theories, 63 HARv. L. REv. 822 (1950); Currie, The Constitution and the Choice of Law: Governmental Interests and the Judicial Function, 26 U. CHI. L. REv. 9 (1958).
} 
strict regimen engendered by the traditional approach has been achieved in some jurisdictions. ${ }^{20}$ The flexibility envisioned by the Court in the instant case made it necessary to recognize this relaxation. In a reiterated dictum highly informative of the Court's present attitude toward the constitutional problems presented by such cases, it was indicated that where more than one state has an apparent basis for having its law applied, the forum may constitutionally analyze those bases in determining which represents an interest sufficient for application of a particular state's law. ${ }^{21}$ It seems apparent, however, that using the "whole" law will permit flexibility only to the extent allowed by conflict-of-laws rules of the state whose law is to be applied.

Although the principal question in the Richards case involves interpretation of a federal statute, that statute only operates within the confines of the state laws. Thus, in undertaking an interest analysis, it is the policies of the states and their interests in enforcing those policies, as represented by their laws, that should be examined. The facts of the instant case present an informative situation for such analysis. Recovery under wrongful death statutes represents a jurisdiction's attempt to preserve to the decedent's dependants an economic position approximating that existing prior to the death. ${ }^{22}$ Limitations on the amount of such recoveries indicate a balancing of the dependants' needs against the danger of an excessive verdict injurious to local economic interests. No policy or interest appears present in the facts of this case to justify application of the Missouri protective policy except the adventitious fact that the airplane happened to crash there. ${ }^{23}$ Thus it would seem

${ }^{30}$ Grant v. McAuliffe, 41 Cal. 2d 859, 264 P.2d 944 (1953); Schmidt v. Driscoll Hotel, Inc., 249 Minn. 376, 82 N.W.2d 365 (1957); Haumschild v. Continental Cas. Co., 7 Wis. 2d 130, 95 N.W.2d 814 (1959). This departure has been strongly advocated in a series of articles by Professor Currie. These articles are listed and extensively criticized in Hill, Govermmental Interest and the Conflict of Laws-A Reply to Professor Currie, 27 U. CHI. L. REv. 463 (1960).

The same result has been reached on the superficial basis of terming limitations of liability to be procedural rather than substantive. Kilberg v. Northeast Airlines, Inc., 9 N.Y.2d 34,172 N.E.2d 526,211 N.Y.S.2d 133 (1961). A favorable analysis of that decision in terms of the interests involved is found in 74 HARV. L. REV. 1652 (1961).

21 This reasoning seems to compare favorably with the position taken by Professor Currie. See especially, The Constitution and the Choice of Law: Governmental Interests and the Judicial Function, 26 CHI. L. REv. 9 (1958) and, The Constitution and the "Transitory" Cause of Action (pts. I-2), 73 HARv. L. REV. 36, 268 (1959).

22 "Damages awarded to widows and orphans under [Lord Campbell's Act] are awarded to compensate dependants of the deceased for the loss of financial support which they would have enjoyed but for the death." 108 L.J. 74I (1958).

${ }^{28}$ Compare Romero v. International Terminal Operating Co., 358 U.S. 354 (1959): 
that the law of the forum should have been applied in the instant case. ${ }^{24}$

The Richards decision, by adopting the state conflict-of-laws rules in actions under the Torts Claims Act unfortunately but unavoidably ${ }^{25}$ will usually require the lower federal courts to follow blindly rules which frequently do not adequately consider the interests of the states involved. However, by recognizing in dictum the governmental interest analysis, the decision may well bring that development into greater prominence. But because the point of Oklahoma law before the Court was at least less than pellucid, ${ }^{26}$ the Supreme Court could have greatly enhanced the stature of the approach by applying it in this case. Moreover, the Tenth Circuit's holding that it was "bound" to apply the Missouri limitation was not based upon an interpretation of Oklahoma law but rather upon decisions involving a conflict between the laws of Colorado and Wyoming. ${ }^{27}$ It is to be hoped that in deciding future cases under the act, where state choice-of-law rules permit, the lower federal courts will not base decisions upon a state's having a fortuitous "contact" with the case, but rather upon a thorough analysis of the pertinent policies to determine if the "contact" represents a valid interest of the state upon which application of that particular law should be predicated.

"The amount and type of recovery which a foreign seaman may receive from his foreign employer while sailing on a foreign ship should not depend on the wholly fortuitous circumstance of the place of injury." Id. at 384 . (Emphasis added.)

"A complete interest analysis requires giving the United States as defendant the characteristics of residence of a particular jurisdiction to determine which policies are pertinent. The possibilities are the state of the injury, the forum state, $c f$. Phillips Chemical Co. v. Dumas Independent School Dist., 361 U.S. 376 (1960), or the District of Columbia, $c f$. Fisher v. Fisher, 250 N.Y. $3^{13}, 165$ N.E. 460 (1929). The discussion in the text indicates there is no strong connection to the place of the injury. In either of the remaining jurisdictions limitless recovery would be available. OKLA. Stat. tit. $12 \S \S 1053,1054$ (1951); D.C. CODE ANN. $\S \S 16-1201$ to I203 (x961).

${ }^{25}$ As an original proposition, it would seem that allowing the federal courts to develop an independent body of law in the tort field would have been a desirable feature of the Torts Claims Act, and would have done away with problems of this nature. Compare Textile Workers Union of America v. Lincoln Mills, 353 U.S. 448 (1957).

${ }^{26}$ The Supreme Court recognized that the Oklahoma conficts-of-law rule on this particular point was drawn from dicta. 369 U.S. at 16 n.35.

Although this was accepted by plaintiffs, it is arguable that the Oklahoma courts might term the limitation procedural. Cf. Edison v. Lewis 325 P.zd 955 (Okla. 1958); compare Kilberg v. Northeast Airline, Inc., 9 N.Y.2d 34, N.E.2d 526, 211 N.Y.S.2d 133 (196I).

"37 Burlington Transp. Co. v. Stoltz, 19 I F.2d 915 (10th Cir. 195I); Stoltz v. Burlington Transp. Co., 178 F.2d 514 (1oth Cir. 1949), cert. denied, 339 U.S. 929 (1950). 